\title{
Yapılandırılmış Senaryo Eşliğinde Maket Üzerinde Adli Ölü Muayenesi Eğitiminin Değerlendirilmesi
}

\section{Evaluation of Forensic Postmortem Examination Training on the Model in Context of Structured Scenario}

\author{
Volkan Zeybek ${ }^{1}$,Kemalettin Acar ${ }^{1}$, Ayşe Kurtuluş Dereli ${ }^{1}$, Cüneyt Orhan Kara² \\ ${ }^{1}$ Pamukkale Üniversitesi Tıp Fakültesi Adli Tıp Anabilim Dall, Denizli \\ ${ }^{2}$ Pamukkale Üniversitesi Tıp Fakültesi Kulak Burun Boğaz Hastalıkları Anabilim Dalı, Denizli
}

\begin{abstract}
Özet
Giriş: Adli ölü muayenesi, mezuniyet sonrası hekimlerin zorlandığı ve hukuki olarak sorunlar yaşadığı bir konudur. Tıp Fakültelerinde adli tıp eğitimi sürecine, adli ölü muayenesi konusunda daha akılda kalıcı ve öğrencilerin ilgisini çekecek düzeyde uygulamalar eklenmesi uygun olacaktır. Bu çalışma, interaktif yöntemlerin uygulanmasında iyi bir model örneği olabilecek "yapılandırılmış senaryo eşliğinde maket üzerinde adli ölü muayenesi” eğitiminin Pamukkale Üniversitesi Tıp Fakültesindeki sonuçlarının ölçülmesi amacıyla yapılmıştır.

Gereç ve Yöntem: Pamukkale Üniversitesi Tıp Fakültesi dönem 5 öğrencilerinden adli tıp taskı almakta olan 88 kişi ve dönem 6 öğrencilerinden halk sağlığı stajını almakta olan 52 kişinin yapılandırılmış senaryo eşliğinde maket üzerinde uygulamalı adli ölü muayenesi eğitimi öncesi ve sonrası bilgi ve beceri düzeyleri ile eğitim hakkındaki görüş ve önerileri standart formlarla değerlendirilmiş, öğrencilerin eğitim öncesi ve sonrası bilgi- beceri düzeyleri karşılaştırılmıştır.

Bulgular: Ön test ve son test cevapları değerlendirildiğinde; bilgi düzeylerinin değerlendirildiği ilk üç soru için dönem 5 öğrencilerinin birinci sorudaki yanıtları dışında tüm öğrencilerin ön test ve son test cevapları arasındaki olumlu farklılık, istatistiksel olarak anlamlı çıkmıştır. Değerlendirme anket formları incelendiğinde; öğrencilerin büyük çoğunluğunun ileride karşılaşacakları ölü muayenesi uygulama ve otopsiye karar verme konusunda kendilerine güvendikleri, bunda da yapılan eğitimin önemli katkısının olduğu anlaşılmıştır. Yazılı geri bildirim veren tüm öğrenciler uygulamanın verimli ve faydalı geçtiğini ve uygulamadan memnun kaldıklarını bildirmişlerdir.

Sonuç: Yaptığımız uygulama mezuniyet öncesi tıp eğitimi çekirdek müfredatında yer alan "adli ölü muayenesi" becerilerinin kazandırılmasında başarılı bir uygulama olmuştur. Bu uygulamamız adli ölü muayenesinin öğretilmesinde diğer tıp fakülteleri için de bir örnek oluşturabilir.

Anahtar kelimeler: Adli Tıp; Ölü Muayenesi Eğitimi; Mezuniyet Öncesi Tıp Eğitimi.
\end{abstract}

\begin{abstract}
Objective: Forensic postmortem examination is an issue that physicians have difficulties and have legal problems. It would be appropriate to add applications that are more memorable and appealing to the students for forensic postmortem examination education in medical faculties. This study was conducted in order to measure the results of the "forensic postmortem examination education on the model in the context of a structured scenario", which may be a good model for the application of interactive methods, at the Faculty of Medicine of Pamukkale University.

Materials and Methods: Eighty-eight 5th term students who were in forensic medicine training and 526 th term students who were in public health training participated in the study. The knowledge and skill levels before and after the training and the opinions and recommendations about the education were evaluated and compared with standard forms.

Results: When pre-test and post-test answers are evaluated; the positive difference between the pre-test and post-test answers of all the students was statistically significant in which the level of knowledge was assessed, except for the first question's answer in 5th term students. When the forms of opinions and recommendations are examined; it was understood that the vast majority of the students had confidence in themselves in the practice of postmortem examination and the decision of the autopsy which they would encounter in the future, all students who gave written feedback reported that the education was fruitful and useful and that they were pleased with this education.

Conclusion: Our practice has been a successful practice in acquiring the skills of forensic postmortem examination which is in the pregraduate medical education core curriculum. This practice can also set an example for other medical schools in the teaching of forensic postmortem examination.
\end{abstract}

Keywords: Forensic Medicine; Postmortem Examination Education; Undergraduate Medical Education.
Sorumlu Yazar: Yrd. Doç. Dr. Volkan Zeybek

Pamukkale Üniversitesi Tip Fakültesi Adli Tip Anabilim Dall, Denizli

E-mail:vzeybek@pau.edu.tr

Geliş: 27.09.2017 Düzeltme: 30.10.2017 Kabul: 31.01.2018

\section{Giriş}

Ülkemizdeki sağlık sistemi ve yasal düzenlemeler sonucunda birinci basamak hekimlerine, adli tıp hizmetleri ile ilişkili çok sayıda sorumluluk yüklenmiştir. Bu işleyiş sırasinda meydana gelen aksaklıklar sebebiyle birinci basamak hekimleri hakkında açılan dava sayısında önemli bir artış gözlenmektedir $(1,2)$. 
Adli tıp uzmanlarının yapması gereken görevlerin çoğu adli tıp uzmanı olmayan hekimler tarafından yapılmasına rağmen, ülke çapında mezuniyet öncesi adli tıp eğitimi standart değildir. Yapılan çeşitli çalışmalar ve toplantılarda, hekimlerin adli tıp hizmetlerini yürütürken karşılaştığı sorunların başlangıcı olarak tıp fakültelerindeki adli tıp eğitiminin yetersiz olması belirtilmiştir (3).

Mezuniyet öncesi adli tıp eğitiminin yeterli olmadığg ve bu nedenle hekimlerimizin adli hekimlik görevini en çok korkulan görev olarak nitelendirdikleri bilinen bir gerçektir $(4,5)$. Birinci basamak hekimlerinin katıldığı bazı çalışmalarda, temel adli tıp sorularının \% 67'sine yanlış yanıt verdikleri, \% 93'ünün mezuniyet öncesi adli tıp eğitimini yetersiz bulduğu saptanmıştır. Mezuniyet öncesi adli tıp eğitiminin araştırıldığı başka bir çalışmada adli tıp anabilim dallarının teorik ders saatleri, pratik ders saatleri, eğitimin veriliş şekli, yapılan uygulamalar, eğitimin verildiği sınıf ve derslerin konu başlıkları arasında önemli farklılıklar olduğu gösterilmiştir (3). Mezuniyet Öncesi Tıp Eğitimi Ulusal Çekirdek Eğitim Programı'nda sağlık süreçlerinde hukuki ve adli durumlarda uygun karar verme, yönetme konusunu mezuniyet öncesi tıp eğitimi ulusal yeterlikler çerçevesi içinde olduğu belirtilmiştir. Adli olgu muayenesi yapma, ölü muayenesi yapma, adli rapor hazırlama ve ölüm belgesi düzenleme gibi konular temel hekimlik uygulamalarının içine alınmıştır. Ulusal Tıp Eğitimi Akreditasyon Kurulu'nun düzenlediği Mezuniyet Öncesi Tıp Eğitimi Ulusal Standartları'nda da, tıp fakülteleri eğitim programlarının tüm aşamalarında, davranış ve sosyal bilimler, tıpta insan bilimleri, adli tıp, toplumsal ve etik öğeler, genel hekimlik becerilerine ilişkin uygulamaların yer alması gerektiği belirtilmiştir (6).

Probleme dayalı aktif eğitim sistemini uygulayan Dokuz Eylül Üniversitesi Tıp Fakültesi'nde dönem 3 öğrencilerine Adli Tıp Anabilim Dalı tarafından bir haftalık bir modül içinde, bir bilgisayar ve giysili bir insan maketi üzerinde, yaptığımız çalışmadaki uygulamaya benzer bir senaryo eşliğinde, hedeflere uygun yönlendirmeler yapılarak "adli ölü muayenesi” konulu bir uygulama yaptırılarak öğrencilere bilgiyi kullanma ve uygulama becerisi kazandırılmaya çalışılmaktadır. Yaptıkları bu uygulamayı tanıttıkları çalışmada, mezuniyet öncesi adli tıp eğitiminde, öğrencilerin pratikte yapmas1 ve aktif olarak katılması mümkün olmayan veya sınır11 olan olgular ve uygulamalar için bilgisayar ve maket destekli eğitim modellerinden yararlanılmasının fakültelerde yaygınlaştırılmasının öğrencilere hekimlik becerisi kazandırmada önemli rolü olacağı kanısında oldukları belirtilmektedir (7).
Pamukkale Üniversitesi Tip Fakültesinde (PAÜTF) probleme dayalı öğrenci merkezli aktif eğitim öğretim sistemiyle eğitim verilmektedir. PAÜTF'nde Dönem 4 ve 5'te hasta başı eğitim, poliklinik uygulamaları, öğretim üyeleri sunumları, seminerler, saha çalışmaları vb. ile zenginleştirilmiş taska dayalı öğrenme uygulanmaktadır. Bu sistem içerisinde adli tıp eğitimi, ilk üç dönemde probleme dayalı öğrenim (PDÖ) modülleri çerçevesinde verilen ve modülle ilişkili konulardan oluşan sunumlar ile dönem 5'te iki hafta süren, sunum, konferans, panel ve uygulamalardan oluşan adli tıp taskından oluşmaktadır. Dönem 5'teki adli tıp taskı kapsamında, senaryo eşliğinde maket üzerinde adli ölü muayenesi uygulamaları gerçekleşmektedir.

$\mathrm{Bu}$ çalışma, interaktif yöntemlerin uygulanmasında iyi bir model örneği olabilecek "yapılandırılmış senaryo eşliğinde maket üzerinde adli ölü muayenesi” eğitiminin Pamukkale Üniversitesi Tıp Fakültesindeki sonuçlarının değerlendirilmesi amacıyla yapılmıştır.

\section{Gereç ve Yöntem}

2016-2017 eğitim öğretim yılında, Pamukkale Üniversitesi Tıp Fakültesi dönem 5 öğrencilerinden adli tıp taskı içinde yapılandırılmış senaryo eşliğinde maket üzerinde adli ölü muayenesi uygulamasına katılan 88 öğrenci ve dönem 6 öğrencilerinden halk sağlığı stajı sırasında yapılandırılmış senaryo eşliğinde maket üzerinde adli ölü muayenesi uygulamasına katılan 52 öğrencinin uygulama öncesi ve sonrası bilgi- beceri düzeyleri ile eğitim hakkındaki görüş ve önerileri standart formlarla değerlendirilmiş, öğrencilerin eğitim öncesi ve sonrası bilgi- beceri düzeyleri karşılaştırılmıştır. Çalışmamız için Pamukkale Üniversitesi Girişimsel Olmayan Klinik Araştırmalar Etik Kurulu'ndan 06.02.2017 tarih ve 60116787-020/8899 sayılı izin yazısı alınmıştır.

Adli ölü muayenesi uygulaması ve çalışma kapsamındaki ön test, son test ile değerlendirme anketi, dönem 5 öğrencilerine iki haftalık adli tıp taskının sondan bir önceki gününde, dönem 6 öğrencilerine ise iki aylık halk sağlığg stajının uygun olan bir gününde yaptırılmıştır.

Her bir uygulama için iki farklı senaryo ve maket hazırlanmıştır. Senaryolar pratisyen hekimin Cumhuriyet Savcısı tarafından ölümlü bir olay yerine davet edilmesiyle başlayıp, olay yerine hareket etmeden önce yapılacak hazırlıklar ve olay yerinde dikkat edilmesi gereken hususlarla ilgili doldurulacak kutucuklar ile ölü muayenesi beceri uygulaması basamaklarından oluşan oturum şeklindedir (Senaryo 1-2). 


\section{Bölüm}

Dr. Ahmet Şentürk Tavas 2 nolu ASM'de görev yapmaktadir. Bir cumartesi akşamı cumhuriyet savcısı tarafindan aranarak ölümlü bir olay meydana geldiğini öğrenir. Savcı 20- 25 dakika içinde geleceklerini ve kendisini araçla alarak olay verine gideceklerini söyler.

Dr. Ahmet Şentürk kendisini almaya gelen resmi plakalı minibüse binerek savcı ile tanışır ve olay yerine doğru hareket ederler.

Bu aşamada cumhuriyet savcısından olayla ilgili neler öğrenmek istersiniz?

\begin{tabular}{l|}
\hline \\
\hline Ölen kiş̧ ile ilgili neler öğrenmek istersiniz? \\
\hline \\
\hline \\
Yanınıza neler almak istersiniz? \\
\hline \\
2. Bölüm
\end{tabular}

Cumhuriyet SavcııI, jandarmadan, akşam kırsal bir alanda alkol alarak sohbet eden ve eğlenen genç bir erkek grubunun bilinmeyen bir nedenle kavga etmeye bașladığını, pek çok kịşinin sopa, taş ve kirik șişe parçaları ile birbirine zarar verdiğini ö̆renir. Olay esnasında gençlerden birisi bilincini kaybederek

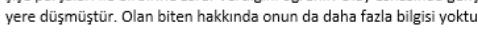

Yeni bilgileri gōzden geçiriniz, olguda hangi türden lezyonlarla karşılaşma olasılığııız olduğunu düşünürsünüz?

\begin{tabular}{|c|}
\hline 3. Bölüm \\
\hline $\begin{array}{l}\text { Olay yerine ulaşııldığında saat 01:00 olmuștur. Olay kasaba dışında büyük çınar ağaçlarının altındaki } \\
\text { bir çeșmenin yaninda geçmiştir. Ceset, su valăğgư hemen yan tarafindaki açık alanda yüzükoyun } \\
\text { yatmaktadır. }\end{array}$ \\
\hline Olay yerinde nelere dikkat etmek istersiniz? \\
\hline 4. Bölüm \\
\hline 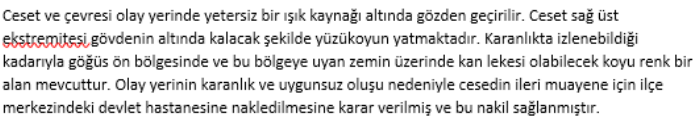 \\
\hline $\begin{array}{l}\text { Size tevdi edilen cesedin medikolegal muayenesini usulüne uygun şekilde yapınız ve bulgularınıı } \\
\text { yazııı. }\end{array}$ \\
\hline
\end{tabular}

Resim 1. Senaryo 1 ve 2: Uygulamada kullanılan senaryolar

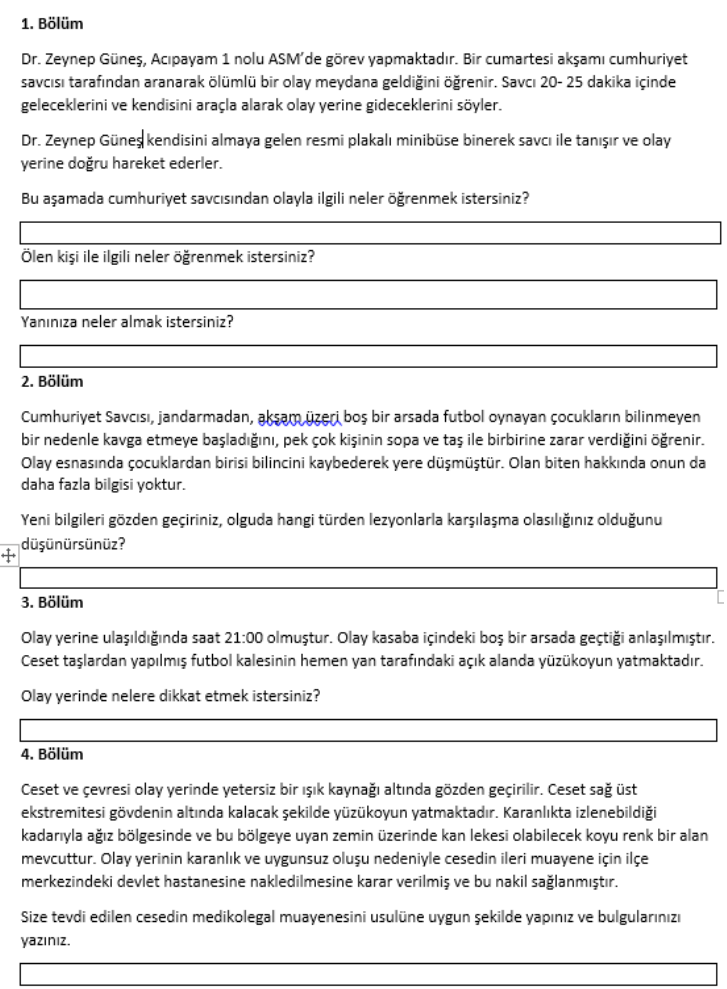

Maketlere senaryolarda tanımlanan lezyonlara uygun yara fotoğrafları yapıştırılıp, maketler uygun şekilde giydirilmiştir. Uygulamalar 14- 15 kişilik gruplar şeklinde yapılmıştır. Öğrencilere uygulamanın başında "ölü muayenesinde aşağıdakilerden hangisi diğerlerinden önce yapılmalıdır?" şeklinde çoktan seçmeli bir soru, "postmortem geç değişikliklerden üçünü yazınız" ve "kişinin ölü olduğunun tespiti için kullanılan üç yöntem yazınız" sorularından oluşan ön test yapılmıştır. Ardından öğren-

\section{ÖNTEST}

1. Ölü muayenesinde așağıdaki basamaklardan hangisi diğerlerinden daha önce yapılmalıdır?

a) Travmatik lezyonların tespiti ve kaydedilmesi

b) Postmortem bulguların tespiti

c) Cesedin tıbbi kimliği

2. Postmortem geç değișikliklerden üç tanesini yazınız:

.................................................

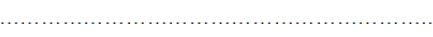

3. Kişinin ölü olduğunun tespiti için nelerden yararlanırız? Üç madde yazını

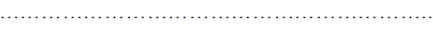

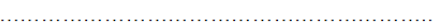

cilere verilen senaryolar grup içinde okunarak olay yeri ve ölü muayenesi ile ilgili sorulara yanıtlar verilmiştir. Maket üzerinde ölü muayenesi uygulaması, öğrencilere işlem basamaklarının yazılı olduğu ölü muayenesi uygulama kılavuzu verilerek yaptırılmıştır. Uygulama sonunda, ön testteki sorulara "ölü katıllı̆ının maket üzerinde gösterilmesi" ş̧eklinde bir uygulama sorusu eklenerek oluşturulmuş son test ve ayrıca bir değerlendirme anketi yapılmıştır (Anket 1).

\section{SONTEST}

1. Ölü muayenesinde așağı̆daki basamaklardan han gisi diğerlerinden daha önce yapılmalıdır?

a) Travmatik lezyonların tespiti ve kaydedilmesi

b) Postmortem bulguların tespiti

c) Cesedin tıbbi kimliği

2. Postmortem geç değişikliklerden üç tanesini yazınız

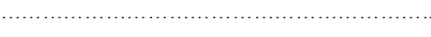

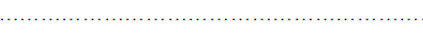

3. Kișinin ölü olduğunun tespiti için nelerden yararlanırız? Üç madde yazın $\mathrm{z}$

. Cesette ölü katılığının gelișip gelișmediğini kontrol ediniz.

Resim 2. Anket 1: Ön test ve son testteki sorular 
Değerlendirme anketi, "bundan böyle tek başıma ölü muayenesi yapabilirim, bundan böyle ölü muayenesini takiben otopsi gerekip gerekmediğine karar verebilirim, ölü muayenesini öğrenmemde bu uygulama eğitiminin önemli katkısı oldu" ifadeleri ve her birinin altında hiç katılmıyorum, ne katıliyorum ne de katılmıyorum, kesinlikle kat1liyorum (1'den 5'e kadar puanlama) ifadelerini içeren likert ölçeği ve sonunda uygulama süreci hakkında ayrıntılı geri bildirim yazmalarının istendiği boş alandan oluşmuştur.

Toplanan nicel veriler bilgisayarda SPSS (Statistical Package for Social Science) 21.0 paket programı ile değerlendirilmiştir. Gruplar arası farklılıkların tespitinde paired samples t-testi kullanılmıştır. Anlamlılık düzeyi $\mathrm{p}<0.05$ olarak belirlenmiştir.

Yazılı geri bildirimler incelenip nitel değerlendirme yapılarak birbirine benzeyen belli kavramlar ve temalar çerçevesinde bir araya getirilip anlaşılır bir düzene sokularak yorumlanmıştır. Araştırmada elde edilen nitel veriler, "genel, öğrenme süreci, öğrenme materyali, öneriler, şikâyetler" şeklinde sınıflandırılarak ayrı ayrı analiz edilmiştir.

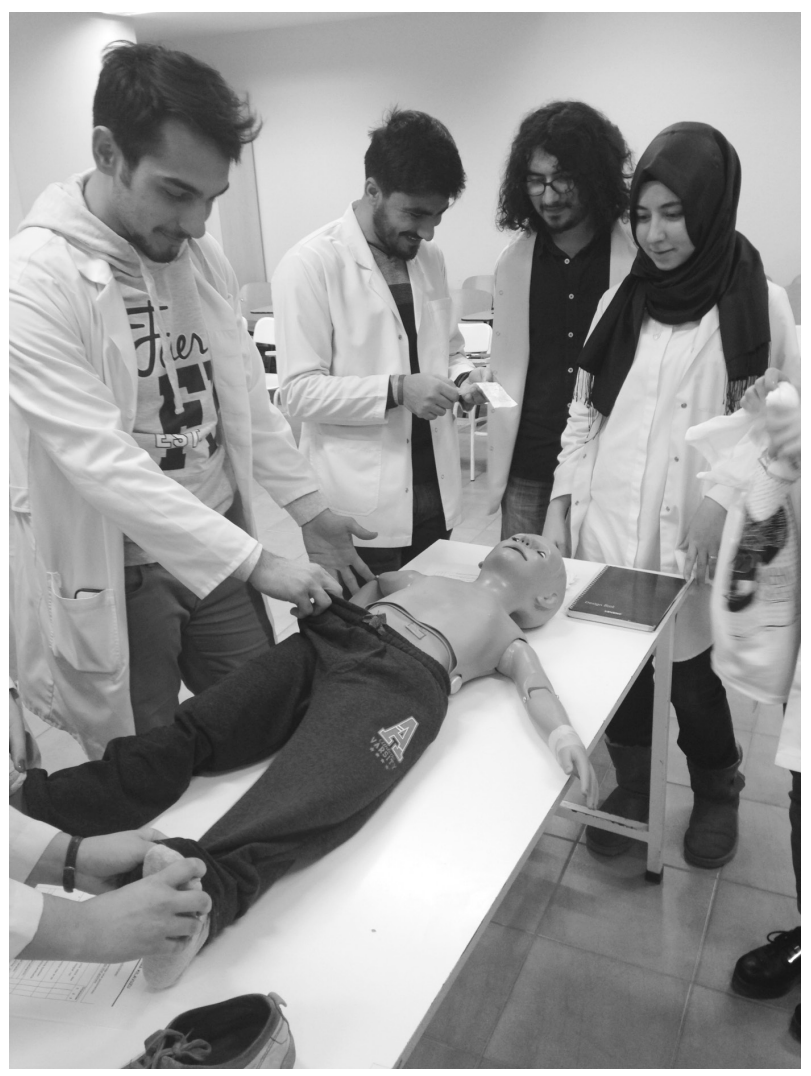

Resim 3. Eğitim sırasında maket başında uygulama yapan öğrenciler

\section{Bulgular}

Çalışmaya katılan öğrencilerin ön test ve son test cevapları değerlendirildiğinde; bilgi düzeylerinin değerlendirildiği ilk üç soru için dönem 5 öğrencilerinin birinci sorudaki yanıtları dışında tüm öğrencilerin ön test ve son test cevapları arasındaki olumlu farklılık istatistiksel olarak anlamlı çıkmıştır $(\mathrm{p}<0.005)$. Beceri düzeylerinin değerlendirildiği, son testte bulunan dördüncü soruyu tüm öğrenciler tam yapmıştır.

Tablo 1. Ön test ve son test cevaplarının dağılımı

\begin{tabular}{|l|l|l|l|l|}
\hline & Dönem5 & & Dönem6 & \\
\hline Sorular & Doğru & Yanlış & Doğru & Yanlış \\
\hline Ön test 1 & $88(\% 100)$ & 0 & $41(\% 79)$ & $11(\% 21)$ \\
\hline Son test 1 & $88(\% 100)$ & 0 & $49(\% 95)$ & $3(\% 5)$ \\
\hline Ön test 2 & $68(\% 21)$ & $20(\% 79)$ & $12(\% 23)$ & $40(\% 77)$ \\
\hline Son test 2 & $82(\% 93)$ & $6(\% 7)$ & $49(\% 95)$ & $3(\% 5)$ \\
\hline Ön test 3 & $62(\% 70)$ & $26(\% 30)$ & $26(\% 50)$ & $26(\% 50)$ \\
\hline Son test 3 & $83(\% 94)$ & $5(\% 6)$ & $51(\% 98)$ & $1(\% 2)$ \\
\hline Son test 4 & $88(\% 100)$ & 0 & $52(\% 100)$ & 0 \\
\hline
\end{tabular}

Değerlendirme anket formları incelendiğinde; 88 dönem 5, 51 dönem 6 öğrencisinin formu doldurduğu görülmüştür. Çalışmaya katılan bir dönem 6 öğrencisinin anket formunu doldurmadı $\breve{g} 1$ belirlenmiştir.

Öğrencilerin büyük çoğunluğunun ileride karşılaşacakları ölü muayenesi uygulama ve otopsiye karar verme konusunda kendilerine güvendikleri, bunda da yapılan eğitimin önemli katkısının olduğu anlaşılmıştır.

Değerlendirme anket formlarında bulunan "Ölü muayenesi bilgi ve becerinizi artırmayı hedefleyen bu ders süreci hakkındaki düşünce ve önerilerinizi geri bildirim olarak ayrıntılı şekilde yazar mısınız?" kısmından elde edilen verilerin nitel yaklaşımla "genel, öğrenme süreci, öğrenme materyali, öneriler, şikâyetler" şeklinde gruplandırılarak içerik analizi yapılmış ve bu gruplara ait cümlelerden örnekler ile birlikte aşağıda sunulmuştur.

\section{Genel}

Yazılı geri bildirim veren tüm öğrenciler uygulamanın verimli ve faydalı geçtiğini ve uygulamadan memnun kaldıklarını bildirmişlerdir.

Gerek dönem 5, gerekse de dönem 6 öğrencileri çoğunlukla, öğrenilen becerilerin sahada çok işlerine yarayacağını, daha güvenli çalışabileceklerini söylemişlerdir.

"Periferde başıma bu tarz bir görev gelme ihtimali beni korkutuyordu, o yüzden kesinlikle faydalı bir uygulama oldu." 
Tablo 2. Anket formlarında belirtilen ifadelere ait likert ölçeklerinin dönem 5 ve 6 dağılımı

\begin{tabular}{|c|c|c|}
\hline \multicolumn{3}{|c|}{ "Bundan böyle tek başıma ölü muayenesi yapabilirim" } \\
\hline & Dönem 5 & Dönem 6 \\
\hline Kesinlikle katıliyorum & $41(\% 47)$ & $12(\% 23)$ \\
\hline Katıliyorum & $46(\% 52)$ & $36(\% 71)$ \\
\hline Ne katıliyorum ne de katılmiyorum & $1(\% 1)$ & $2(\% 4)$ \\
\hline Kesinlikle katılmiyorum & 0 & $1(\% 2)$ \\
\hline \multicolumn{3}{|c|}{ "Bundan böyle ölü muayenesini takiben otopsi gerekip gerekmediğine karar verebilirim" } \\
\hline & Dönem 5 & Dönem 6 \\
\hline Kesinlikle katıliyorum & $33(\% 37)$ & $20(\% 39)$ \\
\hline Katıliyorum & $51(\% 58)$ & $26(\% 51)$ \\
\hline Ne katıliyorum ne de katılmiyorum & $4(\% 5)$ & $5(\% 10)$ \\
\hline \multicolumn{3}{|c|}{ "Ölü muayenesini öğrenmemde bu uygulama eğitiminin önemli katkısı oldu" } \\
\hline & Dönem 5 & Dönem 6 \\
\hline Kesinlikle kat1liyorum & $81(\% 92)$ & $49(\% 96)$ \\
\hline Kat1liyorum & $5(\% 6)$ & $2(\% 4)$ \\
\hline Ne katıliyorum ne de katılmıyorum & $1(\% 1)$ & 0 \\
\hline Kesinlikle katılmıyorum & $1(\% 1)$ & 0 \\
\hline
\end{tabular}

"Mecburi hizmetimizi yaparken bize çok faydası olacağına eminim. Böyle uygulamalar sayesinde kendimize olan güvenimiz artıyor.”

"Mezun olmamıza kısa bir süre kala her hekimin iyi bir şekilde biliyor olması gereken ölü muayenesini verimli bir şekilde anlatılması faydalı oldu."

"Mezun olduktan sonra tek başımıza kaldığımızda başımıza gelecek olan bu tür olayların uygulamalı olarak öğretilmesi aklımızda kalması açısından yardımcı oldu.”

"İlerideki hekimlik hayatıma faydalı bir eğitim olduğunu düşünüyorum, umarım kendimi daha fazla geliştiririm, yanlış şeyler yapmam."

Öğrenme süreci:

En çok uygulama yapılmasından memnun kalmışlardır. Teorik olarak gördüklerini uygulama şansı verilmiş olmasıyla daha kalıcı öğrendiklerini belirtmişlerdir.

Grup çalışması yapmışlar ve birbirlerinin eksiklerini tamamlayarak öğrendiklerini belirtmişlerdir.

"Bu eğitim bilgileri geri çağırma açısından yararlı oldu."

"Derste öğrendiklerimi bir de uygulama firsatı buldum, bu beceriyi kazanmamda çok faydalı oldu."

"Bilgiler havada kalmamış oldu."

“Adli tıp taskı sürecinde yeterince öğrendiğimi düşünmeme rağmen aslında birçok önemli bilgiyi tekrar hatırlamam gerektiğini fark ettim."

"Bu dersin, kesinlikle ölü muayenesini hatırlamamıda çok katkısı oldu."
"Beceri uygulamasında bildiklerimizi gerçekten öğrendiğimizi anladım."

\section{Öğrenme materyali}

PDÖ oturumlarından senaryo üzerinden çalışma alışkanlıkları olduğu için senaryoları gerçek hayata uygun bulmuşlardır. Uygulama yapılan mankenlerin de gerçek hayatı simüle ettiğini düşünmüşlerdir.

"Senaryo üzerinde ilginç ayrıntılar düşünülmüş ve çok gerçekçi yazılmış."

"Kıyafetlerin içinden bazı eşyaların çıkması beni heyecanlandırd1."

"Sanki ölü muayenesi yapar gibi çalıştık."

"Maketlerle ve olay örgüsü şeklinde yapılan uygulamanın katkısı çok oldu."

"Dağıtılan ölü muayenesi uygulama kılavuzlarının ileride çok işimize yarayacağını düşünüyorum."

"Olay sürecinin en başından başlayıp olayı takip ederek soruları cevaplamamız ve olayı sonuçlandırmamız öğrenmemiz açısından önemliydi”

\section{Öneriler}

Öğrencilerin iki ilginç önerileri olmuştur; uygulamanın video ve görsel materyallerle zenginleştirilmesini isterlerken, sahada da uygulama yapılsa daha iyi olur demişlerdir. Ayrıca başka dersler için de bu tür senaryoların kullanılmasının faydalı olacağını belirtmişlerdir.

"Her ne kadar bir olay yerine gidip görmek kadar olmasa da uygulama faydalıydı." 
"Bu tür senaryolarla bazı derslerin de işlenebileceğini düşünüyorum, yine maket üzerine resim yapıştırma ile olabilir."

"Video ve görsel materyal desteği verilebilir."

Şikayetler:

Manken sayısının az olması nedeniyle uygulamadaki gruplarda yer alan kalabalık öğrenci sayısından şikayet etmişlerdir

"3-5 kişiyi geçmeyen gruplar halinde yapılsa çok daha iyi olurdu."

"Daha uzun süreli küçük gruplar halinde daha faydalı olurdu."

"Ders saati uzundu, daha fazla ara verilse daha verimli olurdu."

\section{Tartışma ve Sonuç}

Tıp eğitiminin amaçları ya da sağlık hizmeti organizasyonunda hekimden beklenenler doğrultusunda belirlenen becerilerin, tanımlanmış bir standartta, yapılandırılmış yöntemlerle, laboratuvar ortamında, maket, manken ve standart hastalar kullanılarak kazandırılması yaygın bir yöntemdir (8). Ülkemizde mezuniyet öncesi adli tıp eğitimi ile ilgili çekirdek eğitim müfredatı bulunmasına rağmen bu konuda tanımlanmış bir standart yoktur. Oysa mevcut yasal düzenlemelerle başta ölü muayenesi olmak üzere, pratisyen hekimlere adli tıp ile ilgili pek çok sorumluluk yüklenmiştir. Ülkemizde Adli Tıp Kurumu ve Sağlık Bakanlığı'na bağlı merkezlerin karşılaştırıldığı, 2004 yılında yapılan çalışmada, otopsi raporlarının \% 62.7'sinin, adli raporların \%57.6'sının sağlık ocaklarında verildiği belirlenmiştir (9). Bu konuda yazarlarca daha yeni tarihli bir çalışmaya rastlanmamış olmakla birlikte, aradan geçen yaklaşık on dört yılık zaman diliminde ülkemizde adli tıp uzmanı sayısında sağlanan önemli artış ve neredeyse tüm illerimizde adli tıp uzmanı bulundurabilir hale gelmiş olmamız nedeniyle her ne kadar yazarlar bu oranların giderek düşmekte olduğu kanaatinde olsalar da, pratisyen hekimlerin bu alandaki sorumluluklarının asla ortadan kalkmayacağı unutulmamalıdır. Bu nedenlerle mezuniyet öncesi adli tıp eğitiminin öğrencilere etkili yöntemlerle verilmesi büyük önem taşımaktadır.

Yapılan çalışmalarda pratisyen ve adli tıp dışı uzman hekimlerin adli tıp ile ilgili konularda kendilerini yetersiz hissettikleri, bilgi düzeylerinin yeterli olmadığı belirlenmiştir $(4,5,10)$. Tıp fakültesi öğrencilerinde yapılan başka bir çalışmada ise, adli tıp stajı sonrası adli ölü muayenesi yapma, otopsiye karar verme gibi konu- larda çoğunluğunun kendilerini yeterli bulduğu gösterilmiştir (11). Çalışmamıza katılan öğrenciler task içinde ölü muayenesini hem teorik sunum, hem de gerçek olgu başında uygulama olarak görmüş oldukları halde büyük çoğunluğu uygulama sonrası adli ölü muayenesi yapma ve otopsiye karar verme konularında kendilerini yeterli bulduklarını ve bu uygulamanın adli ölü muayenesini öğrenmelerinde önemli katkısı olduğunu belirtmişlerdir. Nitel bulgularda, öğrencilerin çoğunluğunun bu uygulama ile ilerde karşılaşabilecekleri adli ölü muayenesi işlemini öğrendikleri için memnun oldukları belirlenmiştir. $\mathrm{Bu}$ belirgin memnuniyetin ilerde karşılaşabilecekleri adli olaylarla ilgili endişelerin giderilmesinden kaynaklandığ1 düşünülmüştür.

Beceri eğitiminde 20. yüzyılla birlikte yapıland1rılmış yöntemler uygulanmaya başlanmış, son 25-30 yıldır beceri eğitimi için özel koşullar sağlayan eğitim merkezleri ve laboratuvarlar kurulmaya başlanmıştır (12). Ayrıca web tabanlı e- öğrenme programları da günümüzde yaygın olarak kullanılmaktadır (13). Özdemir ve ark. çalışmamızda yapılan uygulamaya benzer bilgisayar ve manken kullanılarak dönem 3 öğrencilerine yaptıkları uygulamayı tanıttıkları çalışmada uygulamanın başarısını, yıllar içinde dönem 5'e gelen öğrencilerin ilgili task içinde yer alan ders ve uygulamalardaki interaktif katılımları, bilgi, tutum ve davranışlarındaki gelişmelerinden gözlemlediklerini belirtilmektedir (7). Çalışmamızda ön test ile son test arasında her iki sınıf öğrencilerinde de anlamlı fark olması, yapılandırılmış yöntemlerle beceri eğitimi uygulamasının öğrencilerin öğrenmesinde olumlu etkisi olduğunu desteklemiştir. Ayrıca uygulamada kullanılan maket sayısının artırılmasının ve konuyla ilgili video veya görsel materyallerle desteklenmesinin öğrenmede daha da iyi sonuç vereceği kanaatindeyiz. İleriki dönemde anabilim dalı olarak adli ölü muayenesi ve diğer adli tıp konularıyla ilgili daha zenginleştirilmiş materyallerle uygulamalar yapmayı planlamaktayız.

Çalışmamızda "yapılandırılmış senaryo eşliğinde maket üzerinde adli ölü muayenesi” eğitiminin öğrencilerin bu konuyu öğrenmelerinde olumlu katkısı olduğu gösterilmiştir. Ülkemizdeki yasal düzenlemeler gereği, pratisyen hekimlerin adli ölü muayenesi dışında adli tıp hizmetleri ile ilgili çok sayıda sorumlulukları bulunmaktadır. Bu nedenle tıp fakültelerinde adli tıp eğitimi interaktif yöntemlerle ve maket üzerinde yaptırılacak uygulamalarla zenginleştirilerek öğrencilerin daha iyi öğrenmeleri sağlanabilir. 


\section{Kaynaklar}

1. Koç S, Can M. Birinci basamakta adli tıp, 2. Baskı, 2011, https://www.istabip.org.tr/dosyalar/adli_tip.pdf, (İstanbul Tabip Odası web sitesi), Erişim tarihi: 13.09.2017.

2. Tümer AR, Keten A, Karacaoğlu E. Adli olgu bildirimi ve adli raporlar, Hacettepe Tıp Dergisi 2010; 41:128-134.

3. Balc1 Y. Adli tıp hizmet modeli ve insan gücü planlamas1, 2007, Adana, http://www.atud.org.tr/wp-content/uploads/2016/07/hizmet_modeli.pdf, (ATUD web sitesi), Erişim tarihi: 20.09.2017.

4. Turla A, Dündar C. Samsun il merkezinde adli rapor düzenleyen pratisyen hekimlerin adli tıp eğitimi ve adli raporlara yansımaları, OMÜ Tıp Dergisi 2003; 20(3): 119-124.

5. Kumral B, Ozdes T. Assessment of physicians' approaches to the applications of forensic medicine in Tekirdag province. J. For. Med. 2014;28(2):141-53. doi:10.5505/adlitip.2014.76376.

6. Ulusal Tıp Eğitimi Akreditasyon Kurulu. Mezuniyet Öncesi Tıp Eğitimi Ulusal Standartları, http://www.uteak.org.tr/uploads/belge/MOTE_STANDARTLAR_2014.pdf, (UTEAK web sitesi), Erişim tarihi 15.09.2017.

7. Özdemir MH, Demiroğlu Z, Ergönen AT, Salaçin S. Mezuniyet öncesi tıp eğitiminde bilgisayar destekli adli ölü muayenesi uygulaması: bir model çalışma. Adli Tıp Bülteni 2008;13(3):106-112 doi: 10.17986/blm.2008133678.
8. Brown RS, Graham CL, Richeson N, Wu J, McDermott S. Evaluation of medical student performance on objective structured clinical exams with standardized patients with and without disabilities. Acad Med. 2010;85(11):1766-71 doi: 10.1097/ACM.0b013e3181f849dc.

9. Çolak B, Etiler N, Biçer Ü. Adli tıp hizmetleri kim tarafından sunulmaktadır/ sunulmalıdır? Sağlık bakanlığ1 mı? Adalet bakanlığı mı? Toplum ve Hekim 2004; 19 : 134-138.

10. Arslan MN, Abalı F, Özbek BY, Üzün İ. Defin ruhsatı düzenlemede adli boyut: Bir feth-i kabir otopsi olgusu. Türk Aile Hek. Derg. 2015; 19 (2): 114-11.

11. Salaçin S, Çekin N, Özdemir MH, Ş. Kalkan. Mezuniyet öncesi adli tıp eğitimi almış öğrencilere yönelik bir anket çalışması. Adli Tıp Bülteni 1997; 2(1):21 -4 doi: 10.17986/ blm.199721199.

12. Durak Hİ. Mezuniyet öncesi tıp eğitiminde mesleksel beceri eğitimi ve EÜTF'de 1997-1999 yılları arasında birinci sınıf öğrencilerine verilen modüler beceri eğitiminin öğrenciler tarafından değerlendirilmesi (Doktora Tezi). Ege Üniversitesi; 2000.

13. Schmeling A, Kellinghaus M. A web-based e-learning programme for training external post-mortem examination in curricular medical education. Int J Legal Med 2011; 125:857-861 doi: 10.1007/s00414-011-0613-2. 